\title{
Is Social Entrepreneurship Learning for Students Based on Spiritual Experiences Still Relevant?
}

\author{
Arif Julianto Sri Nugroho $^{1} \quad$ Endang Eko Djati Setiawati $^{2} \quad$ Gunawan Budi Santoso $^{3}$ \\ 1. Department of Management, Universitas Widya Dharma J1 KH Dewantara Klaten Republic of Indonesia \\ 2. Department of English Education, Universitas Widya Dharma Jl KH Dewantara Klaten Republic of Indonesia \\ 3. Department of Indonesian Literature and Language Education, Universitas Widya Dharma Jl KH Dewantara \\ Klaten Republic of Indonesia
}

\begin{abstract}
This study aims to develop a learning model through the experience of Muslim entrepreneurial spirit in the social entrepreneurship activities. The objectives achieved in the activities: a. It is gotten the description of strategies of learning model on social entrepreneurship using social business of canvas model, b. elaboration of social entrepreneur learning materials based on spiritual experience.The research design is development research. Data collection techniques use observation, entrepreneurial training based on Muslim entrepreneurial spirit experience, making of Social Business of Canvas Model, waste bank practices and evaluation. Cultivating the spirit of Muslim social entrepreneurship in students includes a sense of belief in God, fear of God, morality, siddiq (honest), amanah (truthful), tabligh (convey), fathanah (smart), discipline, visionary, empathy. The activity was continued with the field practice of making a waste bank in a student domicile and evaluation environment. The results of the activities show a positive and effective value where from the results of the different sample tests. The broader implications are that students are able to form several waste bank communities and they are able to play an active role as innovators and real actors
\end{abstract}

Keywords: experiential learning, Muslim entrepreneurial spirit, social business canvas

DOI: $10.7176 / \mathrm{JEP} / 11-11-03$

Publication date: April $30^{\text {th }} 2020$

\section{Introduction}

The gap in economic income of the rich and the poor in Indonesia is now a national problem that needs to find a solution. Opportunity to access resources for under privileged parties is increasingly limited. A 'pro-poor' national policy and a young generation that is able to foster an entrepreneurial spirit are needed, so that they are able to make social change. One effort to improve these conditions is to grow new social entrepreneurs who are able to increase the economic status of individuals and society

At this time in Indonesia, young people are beginning to fall prey to intolerance, radical in religious behaviour. They feel dissatisfied with their status in the community which is not considered an important part of the community. They are young people who are looking for their identity. This phenomenon of young people behaving radically and intolerantly arises because they do not have access (Williams \& Shepherd, 2016) outside the area where they grow up. They only get information from one-sided social media which is hoax and intolerant in nature (Fox \& D, 2016)(Sukabdi, 2015).

This young man does not have the opportunity to meet other people of different groups, ethnicities, religions and beliefs. Therefore, the social entrepreneurship movement can give young people enlightenment. Changes in perspective from enlightenment can be in the form of empowering individual economies, communities, increasing public literacy, tolerance, health advocacy, arts to religion (Williams \& Shepherd, 2016).

It needs young people who are innovative and active in social entrepreneurial activities. They can be activators to cut the chains of poverty, social problems and inequality of people's income. Viruses to give birth to as many socio-entrepreneurs must be increased, they are true partners of the state and society to overcome various social problems in Indonesia which are currently increasingly complex (Zahra \& Wright, 2015).

The era of higher education in Indonesia, which has global competitiveness, is currently a major need. Higher Education must make serious improvements to all elements of learning. In order that learning held in higher education has superior classes by producing independent graduates, it is necessary for lecturers to present learning that is relevant to contemporary challenges. Learning by lecturers must be in-context rather than out-context (Arends, 2012).

At present the entrepreneurial learning model is the actual issue. The debate over whether entrepreneurship can or cannot be taught is now irrelevant. The majority of the literature observes that entrepreneurship can be taught with successful outputs and outcomes through answering two key questions "what" and "how". This means that the success of entrepreneurial learning depends on the learning model used.

Innovative teaching and learning model is needed to further arouse social entrepreneurial interest among students which is relevant to contemporary challenges. Arends says that the ultimate goal of learning is "to assist students to become independent and self-regulated learners". 
In the experience-based learning model, students are given the task of field research to propose solutions to problems in cases such as the lack of community participation to be aware of environmental cleanliness. Students can experience directly while holding observations in class through various literature-based research objects. From the results of real experiences and observations done students can empower reason to build a concept that serves as a solution to the problem. The concept can be experimented in class with the emergence of the idea of a waste bank social entrepreneurial activity that can be the object of activity (D.Kolb, Boyatziz, \& Mainemelis, 1999).

Some characteristics of individuals who have a social entrepreneurship spirit include being willing to sacrifice and acting immediately when looking at problems in the environment such as garbage, willing to contribute directly by providing solutions to economic and social problems and having practical and innovative properties to overcome various social problems. Someone who has a social entrepreneurial spirit is able to cross ideological boundaries and does not want to be fettered by an established structure because they have the instinct to continue to make changes (Hulgard, 2010).

The concept of socio-entrepreneurship is different from the concept of commercial entrepreneurship. Different approaches to teaching and learning are needed. Growing a successful self-confidence to become a social entrepreneur supported by a spiritual experience-based learning model is very relevant to be applied in Indonesia. The majority of Indonesia's population is 83 percent adhered to Islam from 267 million population. Based on the background of the problem above the formulation of the research problem is "How to form a model of social entrepreneurship learning based on spiritual experience in the form of a Muslim entrepreneurial spirit as an effort to create new social entrepreneurs among competitive students".

\section{Research Method}

Stages of Experimental Research

The initial stage is to carry out a preliminary study by applying a qualitative descriptive approach and conducting a need analysis of the model to be developed. The next stage of the activity is in the form of an experimental study / action research.

\section{Place and time of research}

The research location for the study of spiritual-based social entrepreneur learning study was carried out with the partner of Abdurrahman Bin Auf boarding school in Klaten city. In the next activity students were required to practice an internship with a waste bank social entrepreneur in Surakarta city. The final stage, students were required to carry out real practice of forming a community of waste banks in their own domicile environment. The implementation of experimental studies and model validations were conducted in the period from May 2019 to September 2019.

\section{Data collection technique}

At the exploration stage, the data collection techniques used were observation, making a business model based on the Social Business of Canvas Model, the actual practice of fieldwork (Osterwalder, 2010). In the analysis stage, documentation, analysis of learning models, questionnaires and model validation were carried out.

\section{Results and Discussion Activity Results}

The training activities were carried out in the boarding school environment of Agribusiness Entrepreneur Abdurrahman Bin Auf Klaten for 2 full days in the form of business knowledge training, mental abilities: provision of Muslim entrepreneurship ethos, problem solving, market access knowledge, working capital analysis, product and service offerings, business appropriateness, formation of Social business of canvas model and problem solving.

Activities were carried out in a structured manner in the form of teaching material, question and answer, case study and role playing involving professional mentors. Students play an active role. Presenters insert brainstorming learning and business model making. New ideas for proposing social entrepreneurial activities emerged from students at the session of making Social Business of Canvas Model.

\section{Experience based Learning and formation of Social Business of Canvas Model}

Component description of the eight elements of the Social Business of Canvas Model includes(Lab, 2013):

a. Social Challenges - social challenges in the current situation (quantitative, scale of problem, geographical area), what is the root of the contribution to social problems, whether there is a local wisdom solution to solve social problems, whether there is a way to solve that applies globally / internationally,

b. Beneficiaries - Who are the benefit recipients (age, sex, location of education, profession, experience, marital status, social organization membership), what they need, what they expect,

c. Resources - human resources, financial material, what scientific knowledge are needed,

d. Benefit recipient involvement - What channels are used to involve benefit recipients, how sure you trust the 
benefit recipients, what challenges will arise, why you will involve benefit recipients,

e. Social partners, what business you need, what institutional partners you will involve, what partners' knowledge transfer they can provide you, how you will build intimacy / partnership with your partners

f. Core Activities - What core activities that you will do, what are core activities for benefit recipients,

g. Desired future - What social conditions you want from solving social problems, what outcomes you expect, whether you can quantify outputs in numbers,

h. Social change (impact) How you measure the impact that arises, how you verify these ideas, what can be adapted from the activity process, how you will scale these ideas (market expansion / target groups / social needs).

Training of spiritual experience-based social entrepreneurship was given for two full days divided into three sessions: a) session of success inspiration for social entrepreneurship, b) session of extraordinary self-potential and how to boost the potential of social entrepreneurship, c) session of a million blessing at work, participants are able to be grateful for the overflow of blessings from God Almighty so as to obtain adequate initial energy in starting social entrepreneurial activities (Yuwono \& Partini, 2008).

The essence of the concept of Muslim social entrepreneurship that is implanted includes: the cultivation of a sense of belief in God, fear of God, morality, honest, truthful, convey, smart, discipline, visionary, empathy. The training on waste bank management is continued, observation and the final stage is carried out in the field practice.

\section{Model Test and Discussion}

From the results of the activity model test the participants' understanding before and after the activity was tested through the regression equation model test. The coefficient of the regression value before the activity is positive. This means that if there is an increase in one unit of activity before the training will increase the interest of social entrepreneurs by 0.722 units.

The correlation value obtained by 0.793 has the meaning of fair influence. From the t test, a probability of 0.000 obtained means that Ho was rejected, Ha was accepted. This means that the activity variables before training have a significant influence in growing entrepreneurial interest. The result of the determination coefficient test is 0.615 , meaning that the activities before training affect $61.5 \%$ interest in social entrepreneurs while $38.5 \%$ are influenced by other factors that have not been researched yet in the activity.

The coefficient of regression value after training was obtained positive numbers. This means that if there is an increase in one unit of activity after training it will grow social entrepreneurial interest by 0.835 units. The correlation value obtained after the training of 0.972 has the meaning of a very great influence. From the $t$ test, a probability of 0.000 obtained means that Ho was rejected Ha was accepted. This means that spiritual experiencebased training activities have a significant influence in growing social entrepreneurial interests. The coefficient of determination test result obtained of 0.942 means that training activities have an influence of $94.2 \%$ on the growth of interest in social entrepreneurship while $5.8 \%$ is influenced by other factors that have not been researched yet in research activities.

From the quantitative test and field activities, several findings are found that the direct practice of spiritual experience based learning has relevance to the students' needs. This is proven by the emergence of a waste bank business in the students' domicile environment as the training participants.

Experience based entrepreneurial learning can explore, optimize and channel the students' potentials, talents, interests. This activity has a good impact on participants. After completing training, students have an interest in disseminating the knowledge of social entrepreneurship they have to others.

Changes in behaviour are evident with an increase of motivation, responsibility, creativity, innovation and confidence in learning participants. This is in line with research by (Wulandari, Utomo, \& Narmaditya, 2017), (Hijriah \& Y, 2016) and (Yuwono \& Partini, 2008).

\section{Conclusion}

From the discussion obtained in the previous chapter conclusions are drawn:

The social entrepreneurship learning model based on spiritual experience developed in participant group experimental research is still relevant. The relevance of the activity can be seen from the achievement of learning objectives according to the priorities set, have conformity to learning needs, a positive effect on increasing students' knowledge, attitudes, behaviour, skills. The quantitative results of the model test get positive and significant numbers.

From the conclusions obtained, the following recommendations were formulated:

Abdurrahman Bin Auf Klaten Islamic Boarding School partners should be further involved in other activities related to the learning model. The obstacle faced in the field is the amount of money from the sale of waste bank business conducted by students is not yet stable. The participation of RT (Neighbourhood Association) RW (Villager Association), community and village officials is needed to be involved in the overall activities 


\section{Acknowledgement}

Financial support from the Directorate of Research and Development of the Higher Education Technology Research Ministry of Republic of Indonesia for 2019-2020 Applied Research Scheme Grant is gratefully acknowledged

\section{Disclosure Statement}

The author reported no potential conflict of interest

\section{References}

Arends, R. I. (2012). Learning to Teach (Ninth Ed). New York: McGraw-Hill.

Fox, K., \& D, G. (2016). Terror Attacks in Developed Wold Surge 650\% in one years [online] Available. Retrieved from http://edition.cnn.com/2016/11/16/world/global-terrorism-report/index.html

Hijriah, \& Y, H. (2016). Spiritualitas Islam dalam kewirausahaan. Jurnal Tsaqafah, Jurnal Peradaban Islam, 12(1), $187-208$.

Hulgard, L. (2010). Discourses of Social Entrepreneurship-Variation of the Same Theme?

Kolb, D. ., Boyatziz, R. ., \& Mainemelis, C. (1999). Experiential Learning Theory: Previous research and New Directions. Cleveland, Ohio: Departement of Organizational Behavior Weatherhead School Of Management, Case Western Reserve University

Lab, S. I. (2013). Social Business Model Canvas [online] Available: Retrieved from http://www.cocialbusinessmodelcanvas.com

Osterwalder, A. (2010). Combining Business Business Model Prototyping, Customer Development and Social Entrepreneurship.html. Retrieved from http://www.businessmodelalchemist.com/blog/2010/08

Sukabdi, Z. . (2015). Terrorism in Indonesia: A Review on Rehabilitation and Deradicalization,. Contempory Voices: St Andrew Journal of International Relations, 6(2).

Williams, T. ., \& Shepherd, D. . (2016). Victim entrepreneurs doing well by doing good: venture creation and well-being in the aftermath of a resource shock. Journal of Business Venturing, 31, 365-387.

Wulandari, D., Utomo, S. ., \& Narmaditya, B. . (2017). Waste Bank: Waste Management Model in Improving Local Economy. International Journal Of Energy Economics and Policy, 7(3), 36-41.

Yuwono, S., \& Partini. (2008). Pengaruh Pelatihan Kewirausahaan Terhadap Tumbuhnya Minat Wirausaha,. Jurnal Penelitian Humaniora, 9(2), 119-127.

Zahra, S. A., \& Wright, M. (2015). Understanding the Social Role of Entrepreneurship (June No. 33). 